\title{
Physicists blast US missile defence review
}

\section{Geoff Brumfiel, Washington}

A Pentagon advisory group is considering nuclear-tipped interceptors as a possible alternative to conventional missile defence systems.

But the move has worried scientists studying missile defence technologies. They fear that nuclear interceptors, if ever used, would wipe out vital telecommunications, and that developing them would damage nonproliferation efforts.

Current anti-ballistic-missile systems rely on 'hit-to-kill' strategies, in which interceptors collide with their targets. Hit-to-kill devices destroy nuclear warheads without detonating them - but intercepting a fast-moving missile reliably is technically very challenging, and the devices can be fooled by decoy warheads. Nuclear-tipped warheads could potentially avoid these problems by creating an explosion big enough to knock out any nearby missiles.

Researchers first examined the possibility of using nuclear interceptors in the $1960 \mathrm{~s}$ and 1970s, but the plan was scrapped, in part because of a lack of public support. "It's been off the charts for 30 years. It deserves reexamination," says William Schneider, who chairs the Defense Science Board, the government advisory group that is conducting the new study. The group plans to review several systems, including nuclear interceptors.

Although the blast produced by the inter- ceptors is likely to be high enough in space to avoid any fallout on the ground, it would release an electromagnetic pulse powerful enough to knock out communications satellites and cripple electronics on the surface. "This is sort of a desperate, brute-force solution," says Henry Kelly, president of the Federation of American Scientists. "In a country as dependent as we are on advanced communications and electronics, this would have a devastating effect."

Kelly also notes that new nuclear warheads could require experiments that would end the current moratorium on nuclear testing. The National Nuclear Security Administration, which maintains US nuclear weapons, earlier this year announced plans to design new warheads (see Nature 415, 945; 2002). That programme avoids testing, but Kelly believes that more complex nuclear-tipped interceptors would eventually have to be tested.

Department of Defense officials stress that the current review is extremely preliminary. "We do not have any programme for nuclear-tipped interceptors," says Pentagon spokeswoman Cheryl Irwin.

But even the perception that the United States is considering nuclear interceptors could be harmful, according to Steven Weinberg, a physicist at the University of Texas at Austin who studies missile defence technology. "There has been a kind of taboo against

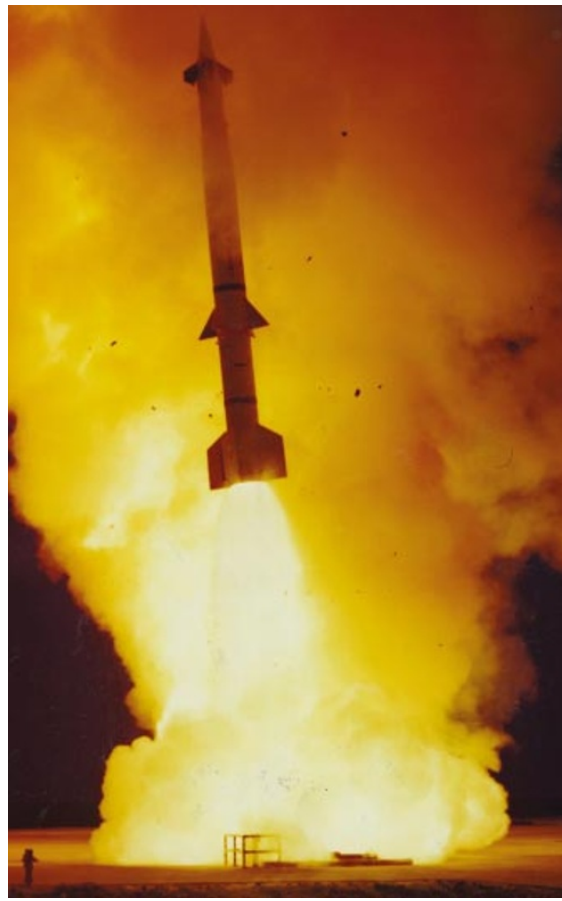

Old idea: plans for nuclear interceptors, such as this Spartan missile, were scrapped in the 1970s.

the use of nuclear weapons - even for peace-time uses. It would be the worst kind of folly for the United States even to be perceived as breaking that taboo," he says.

\section{Chirac's scientific overtures greeted by scepticism}

\section{Sally Goodman, Paris}

France's right-wing president Jacques Chirac has promised to boost innovation and increase public spending on research if he is re-elected.

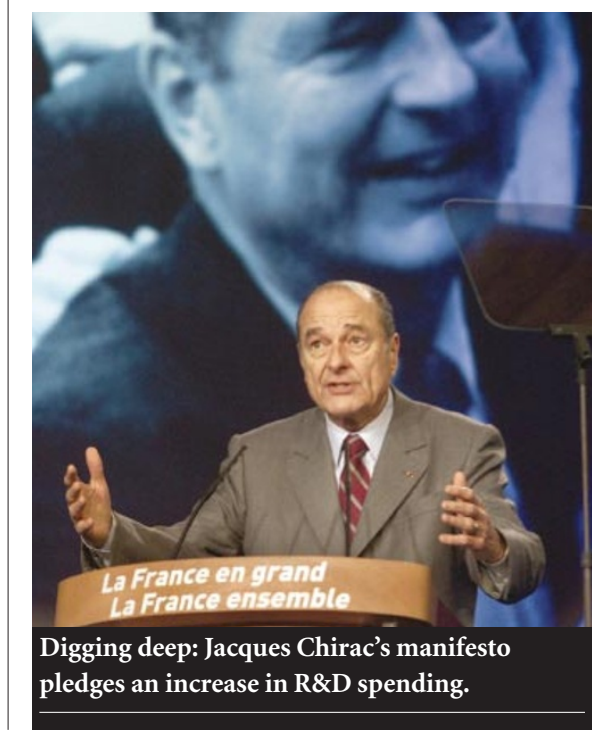

In a manifesto released to Nature, but not yet made public, Chirac pledges to convert the research ministry into a ministry for research and innovation. He wants to boost the mobility of researchers between the public and private sectors and plans tax breaks to encourage corporate R\&D investment.

Chirac also argues that public and private spending on $\mathrm{R} \& \mathrm{D}$ should increase from the current $2.1 \%$ of French gross domestic product to $3 \%$ by the end of the decade. "The commitment to research must be historic," says the manifesto.

Industrial groups welcome Chirac's focus on innovation. But some researchers will be disappointed that the plan does little to address the problems of French universities - which house more than $80 \%$ of the laboratories run by public research agencies. Obstacles to mobility and autonomy for young researchers are a particular concern.

Chirac's rival for the presidency, socialist prime minister Lionel Jospin, has pledged to bring universities and research back under one ministry if he wins the election on 5 May (see Nature 416, 253; 2002).

Many researchers remember their experiences under the last right-wing government, when budgets were cut. "Even if Jospin's track record in terms of research is mixed, that doesn't erase the memory of the 1993-97 period," says Edouard Brézin, a physicist at the École Normale Supérieure in Paris and a former president of the CNRS, France's main agency for basic research.

Gérard Tobelem, a haematologist at the University of Paris VII and national secretary for research in Chirac's RPR party, concedes that research wasn't a priority for the last right-wing government. But he argues that the new plan has "a total awareness of what is now at stake for French science".

In France, the prime minister has ultimate responsibility for science policy. But if parliamentary elections in June go the same way as the presidential election, the new president will be free to appoint a prime minister of his own political persuasion. Chirac and Jospin are currently running neck-and-neck in the opinion polls. 